\title{
Study Analysis of Flue Gas Utilization as Alternative Power Generation in Cement Plant UsingOrganic Rankine Cycle System
}

\author{
Rahmat Ranggonang Anwar, Taufik Fajar Nugroho and Wolfgang Busse \\ Department of Marine Engineering, Faculty of Marine Technology, Institut Teknologi Sepuluh \\ Nopember (ITS) \\ Jl. Arief Rahman Hakim, Surabaya 60111 Indonesia \\ e-mail: taufikfajar@its.ac.id
}

\begin{abstract}
Cement plant produce large amount of heat source in cement making process, due to inefficiency of system there still waste heat available in form of flue gas that can be utilize. Flue gas in cement plant can be utilized as alternative power generation. With the $200-300^{\circ} \mathrm{C}$ temperature output range of flue gas from suspension preheater and air quenching cooler (AQC) in cement plant, organic rankine cycle (ORC) can be suitable option for alternative power generation. $O R C$ is development of rankine cycle, the different is the working fluid in ORC using refrigerant.In cement plant that produce 8466 TPD kiln production, used flue gas from suspension preheater to dry raw material and produce $163888 \mathrm{~m} 3 / \mathrm{h}$ flue gas from AQC that still not utilized. Flue gas with $235^{\circ} \mathrm{C}$ temperature from $\mathrm{AQC}$ can utilized for power generation purpose using ORC system. Waste heat recovery calculation carried out to know the potential recovery. Operating condition of the $\mathrm{ORC}$ system will determine power produced that can be generated and ORC components calculated and selected according to the operating condition of the system.Using R141b as working fluid with 8 bar pressure and $110^{\circ} \mathrm{C}$ temperature inlet to turbine, power produced by turbine is $666 \mathrm{~kW}$. For the components, evaporator and condenser use shell and tube heat exchanger, with evaporator heat transfer area is $676.49 \mathrm{~m} 2$ while condenser has $510 \mathrm{~m} 2$ of heat transfer area. And for working fluid pump it needs $16.235 \mathrm{Kw}$ power to pump R141b back to evaporator.
\end{abstract}

Keywords-Cement plant, Flue gas, Heat exchanger, Organic Rankine Cycle, Power generation

\section{INTRODUCTION}

$\mathrm{N}$ OWDAYS industries sector develop rapidly along with development of technology that support the industries. And development of industries itself need energy to continue the working process. Every process in the industries from the starting process of producing something from raw material until raw material become product that has added value used energy in the making process. Cement industry is one of industry that need large amount of energy to transforming raw material into cement, due to all process mostly used machine to control the production and also need thermal energy.

In the cement making process, the there will be waste heat in form of flue gas that will be available. Usually flue gas will go through stack and wasted to environment with around 200$350^{\circ} \mathrm{C}$ temperature. Flue gas usually come from suspension pre heater and air quenching cooler of cement plant. In some cement plant suspension preheater flue gas used to dry raw material of cement and coal while air quenching cooler flue gas usually out to the stack. The available flue gas can be utilize for another purpose that is as alternative power generation. In cement plant waste heat recovery technology that used as alternative power generation already established since 1970 that developed by Kawasaki Heavy Industry (KHI).

Organic rankine cycle is development from rankine cycle, the component consist of evaporator, turbine, condenser and pump. Working fluid in ORC use refrigerant that has lower boiling point than water. So with the temperature flue gas in cement plant, refrigerant can be in superheated condition to rotate turbine blade and generating power as alternative power generation in cement plant.

\section{LITERATURE STUDY}

\section{A. Organic Rankine Cycle}

The organic rankine cycle different with rankine cycle is the working fluid of the cycle, in ORC it is used refrigerant while in rakine cycle it is used water. Refrigerant has lower boiling point then water, so superheated phase of refrigerant can be made with lower temperature of heat source. This concept that bring ORC cycle can generated alternative power generation utilizingheat source with low temperature.

ORC system consist of evaporator, tubine, condenser and pump. There are four step of work in ORC, this cycle is operate ideally and not involve internal irreversibility. The cycle can be shown with P-h diagram [2]-[4]. The first step is, compression pump will increase the pressure of working fluid and send the working fluid to evaporator. In pump the process condition is adiabatic $(\mathrm{Q}=0)$. After that is evaporation stage where in this process working fluid receives heat by isobaric (assumed that pressure inlet evaporator same as pressure outlet evaporator) from heat source that will used to increase temperature from pump to evaporatorand changing in working fluid phase to superheated vapor. Than working fluid that already in superheated vapor expand and rotate the turbine blade to transmit to shaft generator then to generator to produce power. When the working fluid expand the temperature is decreasing and the pressure as well. The last is condensation stage where in this stage the ideal process also in isobaric condition like in evaporator, in condenser working fluid that expanded from the turbine will be condensed and changing phase into liquid again 


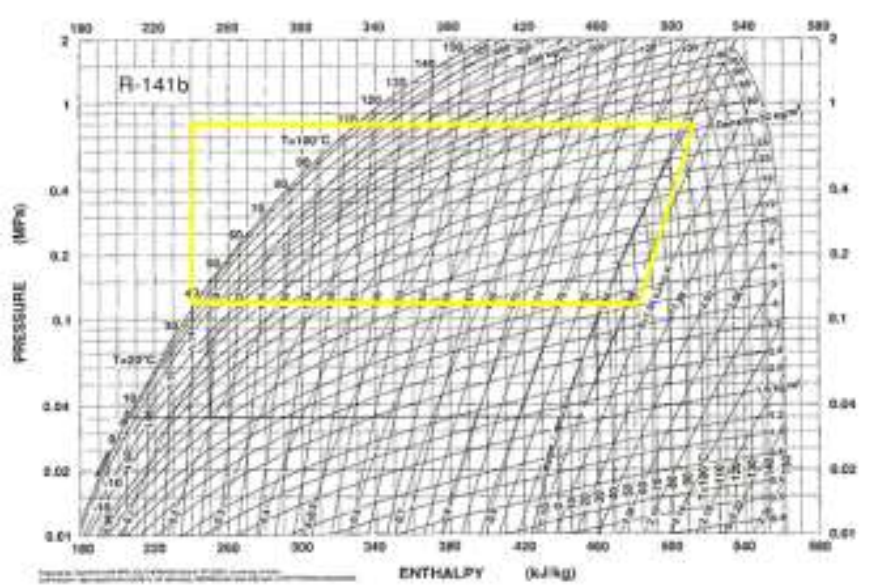

Figure. 1. P-h Diagram and operating condition of R141b Refrigerant (Source :ENSC 388 : Engineering Thermodynamics and Heat Transfer)

Table 1.

Physical and Environmental Data of Some Refrigerant

\begin{tabular}{lllllll}
\hline $\begin{array}{l}\text { Working } \\
\text { Fluid }\end{array}$ & $\begin{array}{l}\text { Type } \\
\text { Of Fluid }\end{array}$ & $\begin{array}{l}\text { Critical } \\
\text { Temp. } \\
\left({ }^{\circ} \mathrm{C}\right)\end{array}$ & $\begin{array}{l}\text { Boiling } \\
\text { Point } \\
\left({ }^{\circ} \mathrm{C}\right)\end{array}$ & $\begin{array}{l}\text { Critical } \\
\text { Pressure } \\
(\mathrm{Mpa})\end{array}$ & $\begin{array}{l}\text { GWP } \\
(100 \\
\text { year })\end{array}$ & ODP \\
\hline R143a & Wet & 84.04 & -47.2 & 3.76 & 0 & 52 \\
R152a & Wet & 66.05 & -24 & 4.52 & 0 & 1.4 \\
R290 & Wet & 44.1 & -42.1 & 4.25 & 0 & 0.041 \\
R717 & Wet & 17.03 & -33.3 & 11.33 & 0 & 0.01 \\
R124 & Isentropic & 136.48 & -12 & 3.62 & 0.02 & 5.8 \\
R134a & Isentropic & 102.03 & -26.1 & 4.06 & 0 & 14 \\
R141b & Isentropic & 204.2 & 32 & 4.21 & 0.12 & 9.3 \\
R142b & Isentropic & 100.5 & -9.1 & 4.06 & 0.07 & 17.9 \\
R123 & Dry & 152.93 & 27.8 & 3.66 & 0.02 & 1.3 \\
R245fa & Dry & 134.05 & 15.1 & 3.65 & 0 & 7.6 \\
R600 & Dry & 58.12 & -0.5 & 3.8 & 0 & 0.018 \\
R600a & Dry & 58.12 & -11.7 & 3.63 & 0 & 0.019 \\
R601a & Dry & 72.15 & 27.8 & 3.38 & 0 & 0.01 \\
\hline \hline
\end{tabular}

and then it get pumped again to the evaporator.

\section{B. Organic Rankine Cycle in Cement Plant}

Waste heat in heat arise from inefficiencies of equipment and thermodynamic limitiation on equipment [1]. In cement plant waste heat in form of flue gas is utilized in burning of clinker in the kiln and cooling of clinker in the air quenching cooler. In the burning of clinker the flue gas will go through suspension preheater and in air quenching cooler flue $g$ as will go to electrostatic precipitator and then to stack. The temperature of flue gas in suspension preheater vary from 300 $400^{\circ} \mathrm{C}$ and in air queching cooler can vary from $200-300^{\circ} \mathrm{C}$. There are some advantages using ORC using flue gas in cement plant like, efficiency of heat energy and electricity, provide economic competitive advantage in the market later and mitigate the emission of green house gases which are affecting the environment. Project payback of ORC system can be vary, higher production of waste heat recovery will have smaller cost per kilowatt of generation capacity and vice versa.[5]-[8]

\section{Refrigerant Selection}

Usually to choose refrigerant there some consideration, like the fouling rate of the refrigerant, corrosiveness, toxicity and flammability of refrigerant, the refrigerant should has as few as possible those factor to minimize risk of loss. And also the working fluid should be safety for the environment, this factor can be rated with the Ozone Depletion Potential (ODP) and Global Warming Potential (GWP). ODP is relative amount of degradation to ozone layer that can caused by the refrigerant. And GWP is measurement of how much a given mass of refrigerant contributes to global warming. The $\mathrm{CO}^{2}$ is the GWP reference, the GWP of carbon dioxide is 1.[9]

The refrigerant usually groups into three according to the slope of saturation of vapor curves in temperature entropy diagram. The fluids having positive slope are dry fluid, the fluids having negative fluids are wet fluid and isentropic fluid the slope is infinite or it can be said that the vapor curve fall in vertical line. From the research that compared wet, isentropic and dry working fluid the ORC, showed that dry and isentropic fluid more likely suitable as working fluid for the ORC cycle due to dry or isentropic fluids are superheated after the expansion process while wet fluid will come into two phase or saturated after the fluid goes through turbine that can make droplets and damage the turbine especially turbine's blade.

\section{Heat Exchanger(Evaporatorand Condenser)}

The use of heat exchanger is very important in many industrial process like in refrigeration system, cryogenic, heat recovery, alternate fuel, etc. Some of heat exchanger commonly used in our daily life like air conditioner and water heater. In ORC system there are two heat exchanger, that is evaporator and condenser. Heat exchanger is device to transfer thermal energy from two fluid that has different temperature. In heat exchanger the fluid is not mix, the fluid separated in different area.

Heat exchanger classified into several category according to, construction, transfer process, degrees of surface compactness, flow arrangements, pass arrangements, phase of process fluids and heat transfer process. And according to their construction heat exchanger classified into, tubular heat exchanger, plate heat exchanger and extended surface heat exchanger.[10]

In this research shell and tube heat exchanger will be used due to it is most common heat exchanger used because of its versatility that can be used in any condition and situation and also easy to maintain. And to make preliminary design of Heat exchanger first is calculate the heat transfer rate $(\mathrm{Q}(\mathrm{kJ} / \mathrm{s}))$.

$$
\mathrm{Q}=\mathrm{m} \times \mathrm{Cp} \times \Delta \mathrm{T}
$$

And to design it, log mean temperature diffenrence (LMTD) and LMTD correction (F) factor need to be calculated. For LMTD the formula is

$$
\Delta \mathrm{LMTD}=\frac{\left(T_{h i}-T_{c o}\right)-\left(T_{h o}-T_{c o}\right)}{\ln \frac{\left(T_{h i}-T_{c o}\right)}{\left(T_{h o}-T_{c o}\right)}}
$$

After that assume overall heat transfer coefficient $\left(\mathrm{U}\left(\mathrm{W} / \mathrm{m}^{2} . \mathrm{K}\right)\right)$, then required heat transfer area can be calculated 


$$
\mathrm{A}=\frac{\mathrm{Q}}{\mathrm{U} \times \mathrm{F} \times \mathrm{LMTD}}
$$

Then actual heat transfer area can be calculated by assuming geometry data with trial and error until finding proper composition. To calculate actual heat transfer area shell diameter, length of tube and number of tube data is needed

$$
\mathrm{A}=\pi \times D_{s} \times L \times N_{t}
$$

Next stage is calculating tubeside heat transfer coefficient, shellside heat transfer coefficient and shellside correction factor.

To calculate tubeside heat transfer coefficient $\left(\mathrm{W} / \mathrm{m}^{2} . \mathrm{K}\right)$, reynold number, prandtl number must be known

$$
\frac{h_{t} \times I D}{\mathrm{k}}=0.0243 \times \operatorname{Re}^{0.8} \times \operatorname{Pr}^{n}
$$

And to calculate tubeside heat transfer coefficient $\left(\mathrm{W} / \mathrm{m}^{2} . \mathrm{K}\right)$, ideal colburn $\mathrm{J}$ factor, side mass velocity $\left(\mathrm{kg} / \mathrm{m}^{2} . \mathrm{s}\right)$, Viscocity correction factor and Prandtl number need to be calculated first

$$
h \mathrm{i}=\frac{j i \times C p \times G s \times(\phi s)^{n}}{\operatorname{Pr}^{2 / 3}}
$$

Flow fraction for each stream is found by knowing the corresponding flow areas and flow resistance. The heat transfer coefficient for ideal crossflow is then modified for the presence of each stream through correction factor with BellDelaware method. The heat transfer in the shell side then modified for the presence of each stream through correction factors (hs). After that overall heat transfer coefficient (U) value can be found, if the value is not near the assumption value in the first, then try with another geometry data until the value error of $\mathrm{U}$ is close (0-5\%). Overall heat transfer coefficient can be calculated with

$$
U=\frac{1}{\frac{1}{h_{s}}+R f_{s}+\frac{t_{w}}{k_{w}}+\frac{A_{o}}{A_{m}}+\left(R f_{t}+\frac{1}{h_{t}}\right) \frac{A_{o}}{A_{i}}}
$$

And after calculate the actual heat transfer area again with the $U$ value from last calculation of $U$. After that calculate tube side and shell side pressure drop with kern method. The allowable pressure drop both on tube and shell side is not more than 10 psi [11]. If the pressure drop more than 10 psi geometry data can be change either decrease number of tube pass, increase tube diameter, increase baffle spacing or increase tube pitch. To calculate it this following formula can be use

Tubeside:

$$
\Delta P_{t}=\frac{f \times G t^{2} \times L \times n p}{5,22 \times 10^{10} \times I D \times S g \times \phi_{s}}
$$

Shellside

$$
\Delta P_{s}=\frac{f \times G s^{2} \times D s \times(n b+1)}{5,22 \times 10^{10} \times d e \times S g \times \phi_{s}}
$$

\section{E. Turbine}

Turbine is one of main part in ORC, in turbine, the refrigerant that already in superheated phase will be expand in turbine, the expansion of refrigerant will give energy to turbine to rotate shaft generator then later transmit the energy from shaft to generator and produced the power. The refrigerant that already in expand will decrease in temperature and pressure.

To choose turbine in ORC the consideration is capacity of the turbine, maximal pressure and temperature that can handle by the turbine. To calculate the power output by the turbine this following equation can be used:

$$
W \mathrm{t}=\mathrm{m} \times\left(\mathrm{h}_{2}-\mathrm{h}_{1}\right)
$$

\section{F. Pump}

Pump used to move fluid from one place to another place, the fluid that through the pump is liquid. In organic rankine cycle main requirement of pump is, to increase the pressure of fluid and send it back to the evaporator, higher pressure that will lead into higher power production of the turbine. When selecting pump, the thing that must be known first is the capacity of the flow or flowrate of the fluid and head minimum required for pumped the fluid then the pumping power will be known from that. Beside that other requirement for selecting pump is suction and discharge condition, type of fluid, work hour of pump and installation location of the pump.[12]

To select pump, pump capacity and head need to be known.To calculate it can be expressed with this formula : Capacity

$$
Q=\frac{\mathrm{m}}{\rho}
$$

Total Head (m) which is addition from head pressure, head velocity, head static and head frict0ion

$$
H=H_{p}+H_{v}+H_{s}+H_{f}
$$

\section{METHODOLOGY}

In this bachelor thesis the first stage is literature study, the literature study is about thermodynamic study of the cycle, making operating condition of ORC, refrigerant selection and also manual calculation for every components (evaporator, turbine, condenser and pump) to design and selecting the components. Next stage is collecting data from cement plant, the data is about flue gas from suspension preheater and air quenching cooler, and also the properties of flue gas like temperature output, pressure, flowrate, density, specific heat, flue gas composition and also space available to make ORC system.

After flue gas data in cement plant obtained, then analyzed whether the flue gas already used for another purpose or not, and the result is, flue gas in suspension preheater already used 
to dry raw material and also coal in cement plant, and from air quenching cooler, flue gas is used just to ensure the cement is already dry and there are still many flue gas go through stack that can utilize for making ORC system.

Then refrigerant selected based on several criteria like thermal efficiency, physical properties of refrigerant and also effect to environment. After refrigerant selected operating condition of ORC can be made with suitable temperature and pressure so the cycle can run properly. From that the power produced from the ORC can be calculated and also requirement of heat in heat exchanger can be known.

And after that the components is calculated to select and design it. For heat exchanger (evaporator and condenser) calculated to know the geometry data of heat exchanger so it is known the need of heat exchanger, shell and tube heat exchanger selected due to easiness to maintain and flexibility in preliminary design, even it is used more space than another type due to space available in cement plant is plenty big $(36 \mathrm{~m}$ $\times 19 \mathrm{~m})$ so it wont be problem. The calculation of heat exchanger carried out with trial and error calculation due to geometry data of heat exchanger must be appropriate for heat requirement in evaporator and condenser. And turbine selection can be conducted through operating condition of ORC system from inlet temperature and pressure and also power output of ORC system turbine can be selected. The last component is pump, to select pump the first calculation is calculating the pump capacity followed with calculating pump head (pressure head, static head, velocity head and friction head), after that pump product can be selected.

Table 3.

Geometry Data Assumption of Evaporator

\begin{tabular}{lc}
\hline \multicolumn{1}{c}{ Area } & Parameter \\
\hline Tube Outside Diameter (OD) & $0.0254 \mathrm{~m}$ \\
Tube Inside Diameter (ID) & $0.0214 \mathrm{~m}$ \\
Tube Pitch (PT) & $30^{\circ}$ \\
Shell Diameter (Ds) & $1.084 \mathrm{~m}$ \\
Length of Tube & $8.8 \mathrm{~m}$ \\
Baffle Spacing & $0.976 \mathrm{~m}$ \\
Number of Baffle & 9 \\
Baffle Cut & $25 \%$ \\
\hline \hline
\end{tabular}

After all analysis and calculation carried out conclusion can be created and also suggestion to develop the research about this bachelor thesis.

\section{ANALYSIS AND DISCUSSION}

A. Data Analysis

Table 2.

Heat Source from Air Quenching Cooler

\begin{tabular}{llll}
\hline \hline Area & Parameter & Quantity & Unit \\
\hline & Velocity & 8.81 & $\mathrm{~m} / \mathrm{s}$ \\
& Specific Heat & 0.237736 & $\mathrm{kcal} / \mathrm{kgC}$ \\
& Temperature & 235 & ${ }^{\circ} \mathrm{C}$ \\
& Pressure & 27.54 & $\mathrm{mmWG}$ \\
Cooler Excess Air & O2 & 21.0 & $\%$ \\
& CO & 0 & $\mathrm{ppm}$ \\
& CO2 & 0 & $\%$ \\
& Nox & 0 & $\mathrm{ppm}$ \\
& Diameter & 3 & $\mathrm{~m}$ \\
& Flow Rate & 381135 & $\mathrm{~m} 3 / \mathrm{hr}$ \\
\hline \hline
\end{tabular}

Due to the flue gas in suspension preheater is used. This research source of flue gas is using flue gas from air quenching cooler in cement plant. From on $31^{\text {st }}$ January 2015, and the data is. And for the density of air is $1.29 \mathrm{~kg} / \mathrm{m}^{3}$.

From that the potential power generation is $6.08 \mathrm{MW}$. After that refrigerant is selected, with $235^{\circ} \mathrm{C}$ temperature output R141b will be suitable, due to it will be in superheated phase with particular operating condition.

And for the operating condition of ORC system is set $110^{\circ} \mathrm{C}$ temperature outlet and 8 bar of R141b when it is out from evaporator with superheated phase of R141b and $64.06^{\circ} \mathrm{C}$ and 1.5 bar when it is out of the turbine. And after leaving condenser R141b will become liquid with $34^{\circ} \mathrm{C}$ temperature and 1.417 bar pressure, after that it will get pumped with the increase of pressure up to 8.004 bar. And for flue gas output temperature is $100^{\circ} \mathrm{C}$.

From that operating condition the power output of turbine is $666 \mathrm{~kW}$ and for the requirement of condenser is 5488.3 $\mathrm{kJ} / \mathrm{s}$.After that ORC components can be calculated and selected.

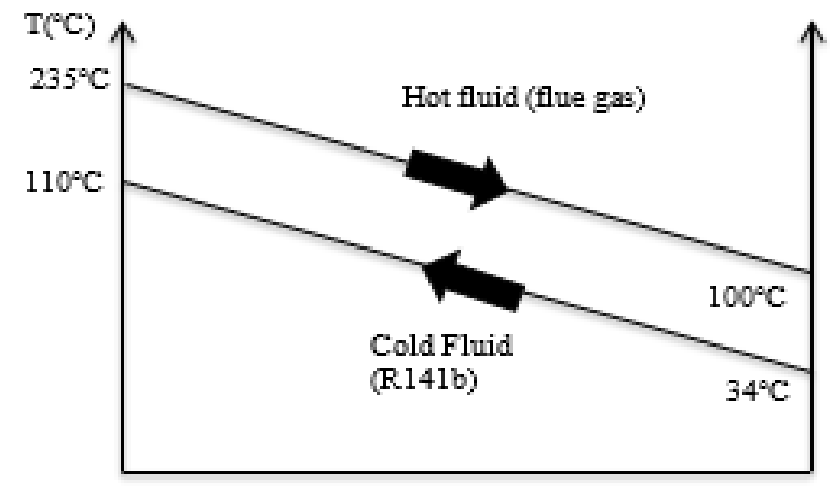

Figure. 2. Evaporator Operating Condition

\section{B. Evaporator}

The flow of the evaporator is counter flow according to the operating condition in the Figure 2. And with the heat transfer rate $6080 \mathrm{~kJ} / \mathrm{s}$ the geometry data assumption is 
Table4.

Evaporator Calculation Summary

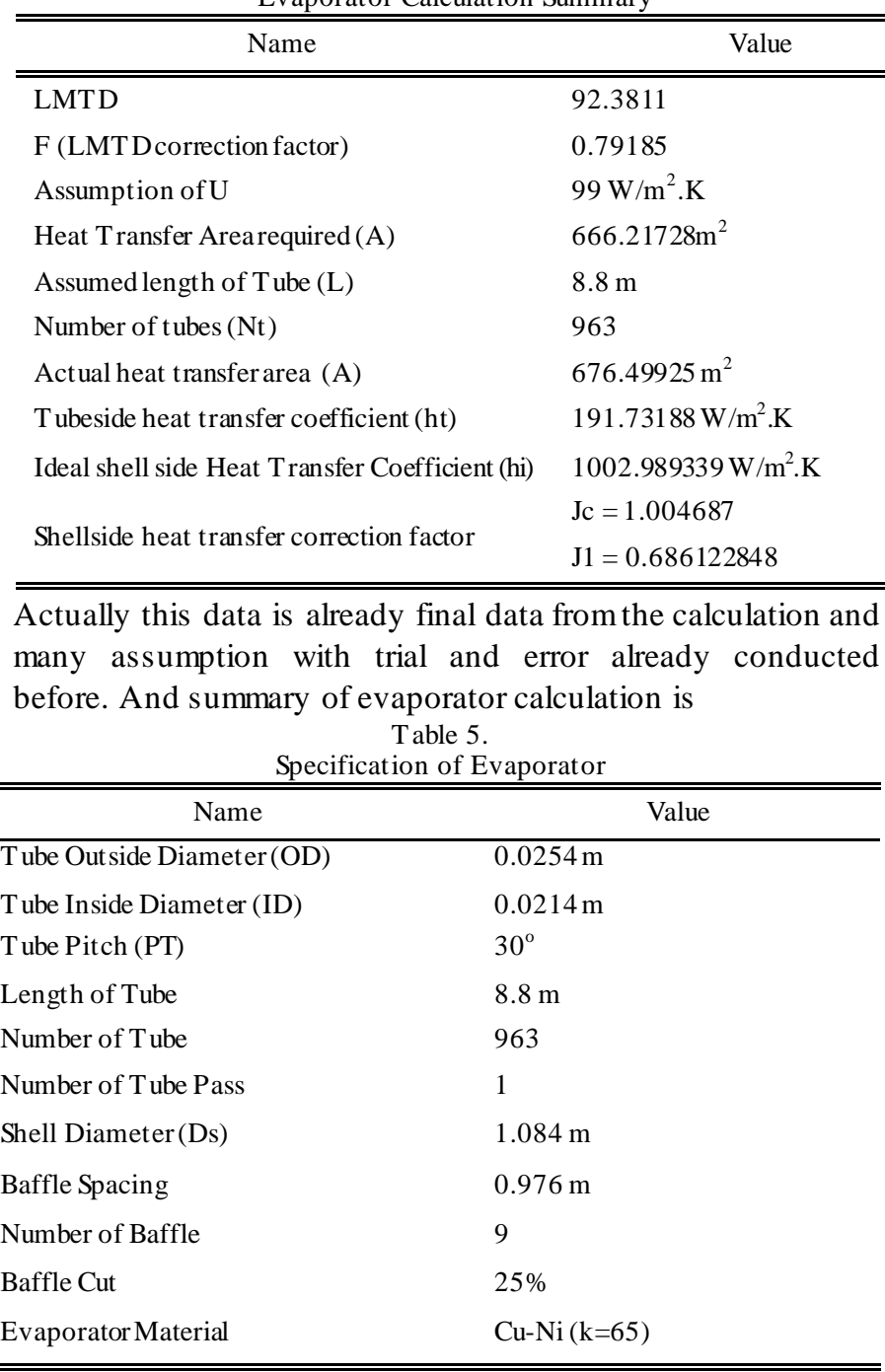

From the calculation, specification of evaporator can be determined, and the specification is shown in table 5.

\section{Turbine}

With the operating condition that already set from the P-h diagram, it is already known that the power produced from the turbine is 666.0697 watt. And to choose the turbine the setting

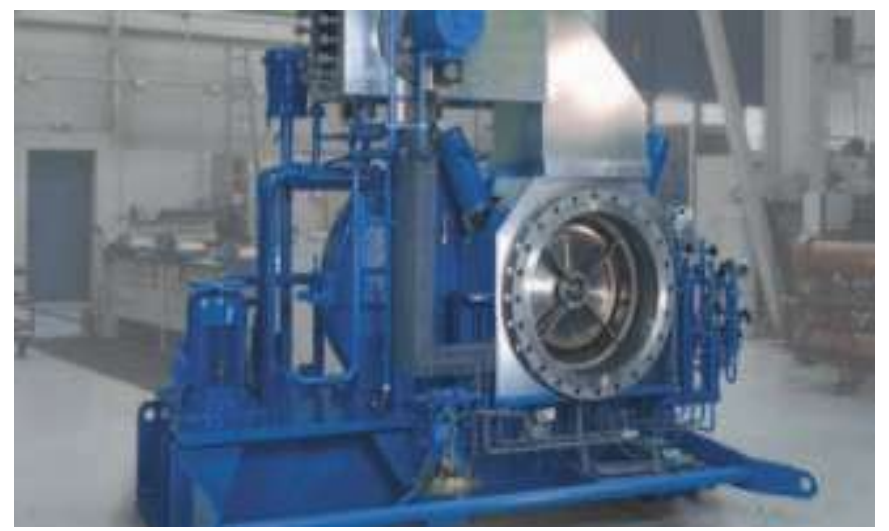

Figure.3. Siemens SST 060 Turbine

(Source : Predesigned Steam Turbine) parameter is inlet temperature to the turbine, inlet pressure to the turbine and the maximum power output from the turbine.

And from that where the operating condition of this ORC system, where the inlet temperature is $110^{\circ} \mathrm{C}$ and the inlet pressure is 8 bar with the power output 666.0697 watt. Siemens SST 060 chosen for this ORC system.

\section{Condenser}

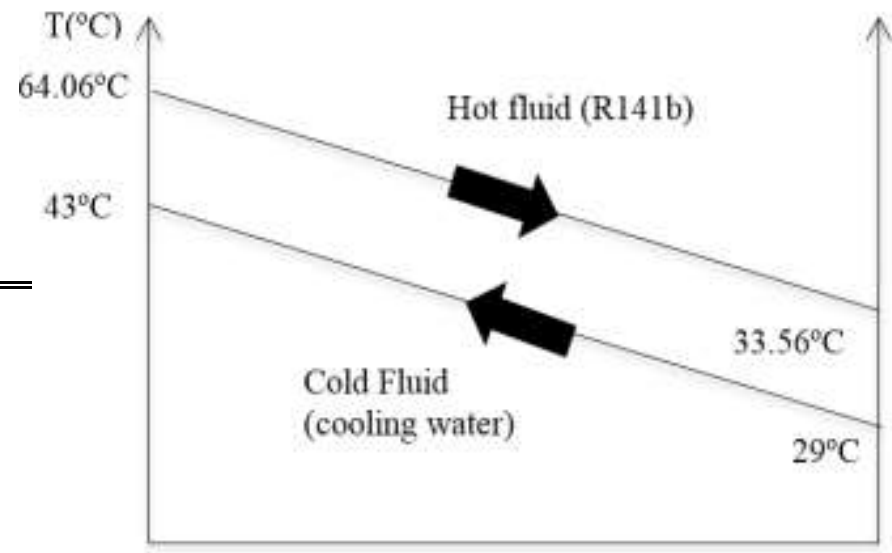

Figure. 4. Condenser Operating Condition

The step to design the condenser is same like the evaporator due to the condenser is shell and tube heat exchanger as well.

Table 6.

Condenser Calculation Summary

\begin{tabular}{ll}
\hline \multicolumn{1}{c}{ Name } & \multicolumn{1}{c}{ Value } \\
\hline \hline LMTD & 10.7839 \\
F (LMTD correction factor) & 0.822586 \\
Assumption of U & $850 \mathrm{~W} / \mathrm{m}^{2} . \mathrm{K}$ \\
Heat Transfer Arearequired (A) & $727.881 \mathrm{~m}^{2}$ \\
Assumed length of Tube (L) & $9 \mathrm{~m}$ \\
Number of tubes (Nt) & 1031 \\
Actual heat transfer area (A) & $740.7293 \mathrm{~m}^{2}$ \\
Tube side heat transfercoeffficient (ht) & $1863.058 \mathrm{~W} / \mathrm{m}^{2} . \mathrm{K}$ \\
Shell side Heat TransferCoefficient & $1500.431 \mathrm{~W} / \mathrm{m}^{2} . \mathrm{K}$ \\
& $\mathrm{Jc}=1.028437$ \\
Shell side heat transfercorrection factor & $\mathrm{J} 1=0.94627$ \\
& $\mathrm{Jb}=0.83333$ \\
& $\mathrm{Js}=1$ \\
Ideal shell side Heat Transfer Coefficient (hi) & $1141.235 \mathrm{~W} / \mathrm{m}^{2} . \mathrm{K}$ \\
Overall heat transfer coefficient (U) & $858.2355 \mathrm{~W} / \mathrm{m}^{2} . \mathrm{K}$ \\
Tubeside Pressure Drop & $0.268896 \mathrm{bar}$ \\
Shellside Pressure Drop & $0.67086 \mathrm{bar}$ \\
\hline \hline
\end{tabular}

This part will only show the summary of the condenser calculation.With the requirement of heat rate in condenser Summary calculation of condenser $5488.3 \mathrm{~kJ} / \mathrm{s}$, the calculation of requirement of condensershown in table 6 . 
Table 7.

Specification of Condenser

\begin{tabular}{ll}
\hline \multicolumn{1}{c}{ Name } & \multicolumn{1}{c}{ Value } \\
\hline \hline Tube Out side Diameter(OD) & $0.0254 \mathrm{~m}$ \\
Tube Inside Diameter (ID) & $0.0214 \mathrm{~m}$ \\
Tube Pitch (PT) & $30^{\circ}$ \\
\hline
\end{tabular}

From the calculation, specification of evaporator can be determined, and the specification is shown in table 7.

Table 7. (Continue)

Specification of Condenser

\begin{tabular}{|c|c|}
\hline Name & Value \\
\hline Length of Tube & $9 \mathrm{~m}$ \\
\hline Number of Tube & 1031 \\
\hline Number of Tube Pass & 1 \\
\hline Shell Diameter(Ds) & $1.2 \mathrm{~m}$ \\
\hline Baffle Spacing & $1 \mathrm{~m}$ \\
\hline Number of Baffle & 9 \\
\hline Baffle Cut & $25 \%$ \\
\hline Evaporator Material & Alumunium Brass $(\mathrm{k}=100)$ \\
\hline
\end{tabular}

diameter. Due to it consume large place the choosing of shell and tube HE must be considered as well.

\section{REFERENCES}

[1] Johnson I, Choate T W, Waste Heat Recovery : Technology and Opportunities in U.S. Industry, Research Report, 2008.

[2] Kusumaning, A F., Cahyono, B., Soemarojo., AnalisaSistem Organic Rankine Cycle (ORC) Menggunakan Gas BuangMesin Diesel di KapalSebagaiInovasiPembangkitListrik, Scientific Journals, 2015.

[3] Bardani B. Z. PerancanganSistemKogenerasipadaPabrik Semen PT Holcim Indonesia Plant Cilacap. Yogyakarta, 2015.

[4] Jayaraman G. Manual onWaste Heat Recovery in Indian cement Industry, Conferderation of Indian Industry. Hyderabad, Research Report, 2009.

[5] Bergman, T. L., Lavine A. S., Incorpera, F. P., Dewitt, P. D. 2011. Fundamentals Of Heat and Mass Transfer. $7^{\text {th }}$ ed. Jefferson City. John Wiley and Sons Inc.

[6] Habibzadeh, A., Rashidi M M., 2016. “Thermodynamic Analysis Of Different Working Fluids Used In Organic Rankine Cycle For Recovering Waste Heat From GT-MHR”. Journal of Engineering Science Technology.

[7] Thulukkanam, K. 2013. Heat Exchanger Design Handbook. $2^{\text {nd }}$ ed. Boca Raton. CRC Press.

[8] Sularso., Tahara, H., 2000. Pompa Dan KompressorPemilihanPemakaiandanPemeliharaan. $7^{\text {th }}$ ed. Jakarta. PT PradnyaParamita

\section{E. Pump}

To select pump for the refrigerant, capacity and head of the pump must be calculate first, than also the pumping power of the pump. Ant below is the step and equation to select pump.

From the calculation found that pump capacity is 65.8681 $\mathrm{m}^{3} / \mathrm{h}$.

And for head calculation, the pressure head is $55.4588 \mathrm{~m}$, static head is $0 \mathrm{~m}$, velocity head is $0 \mathrm{~m}$ and for friction head is $0.9192 \mathrm{~m}$ so the total head of the pump is $56.3779 \mathrm{~m}$

And the power needed of the pump with the assumption of efficiency $75 \%$ will require $16.392 \mathrm{~kW}$ of power of pump motor.

\section{SUMMARY}

1. In cement plant, flue gas from preheater already used for raw grinding purpose, and flue gas in air quenching cooler used in cement grinding to ensure that the cement already fully dried, but there is still many flue gas from air quenching cooler go through stack due to the need in cement grinding not so high. So the flue gas from air quenching cooler that go through stack can be used for alternative power generation using ORC 2. Operating condition of ORC will affect power produce in the turbine, higher pressure that can be achieve can make power produce will be higher too. In this case from the $8 \mathrm{bar}$ and $110^{\circ} \mathrm{C}$ inlet to turbine and $1.5 \mathrm{bar}$ and $64.06^{\circ} \mathrm{C}$ in outlet of turbine with the mass flow rate $22.25245 \mathrm{~kg} / \mathrm{s}$ can produce 666 $\mathrm{kW}$ of power.

3. Shell and tube heat exchanger are the most used HE in the world and it is easier to maintain and used. But the shell and tube will spend large enough space if the requirement is high. The evaporator with the $6 \mathrm{MW}$ requirement need 8.8 meter long and 1.084 meter of shell diameter, and for $5.5 \mathrm{MW}$ requirement condenser need 7.9 meter long and 1 meter shell 